\title{
Protective effect of Phaleria macrocarpa (Scheff.) Boerl extract on the testicular damage of streptozotocin and nicotinamide-induced type 2 diabetic rats
}

\author{
Evy Sulistyoningrum ${ }^{1 *}$, Danny Martha Pradipta², Sausan Fanana ${ }^{2}$, Jamilah Aulia Haikhah ${ }^{2}$, \\ Malombassi Dharmawan Hadiwidjojo Putro ${ }^{2}$ \\ ${ }^{1}$ Histology Department, Faculty of Medicine, Islamic University of Indonesia, Yogyakarta, Indonesia. \\ ${ }^{2}$ Student of Faculty of Medicine, Islamic University of Indonesia, Yogyakarta, Indonesia.
}

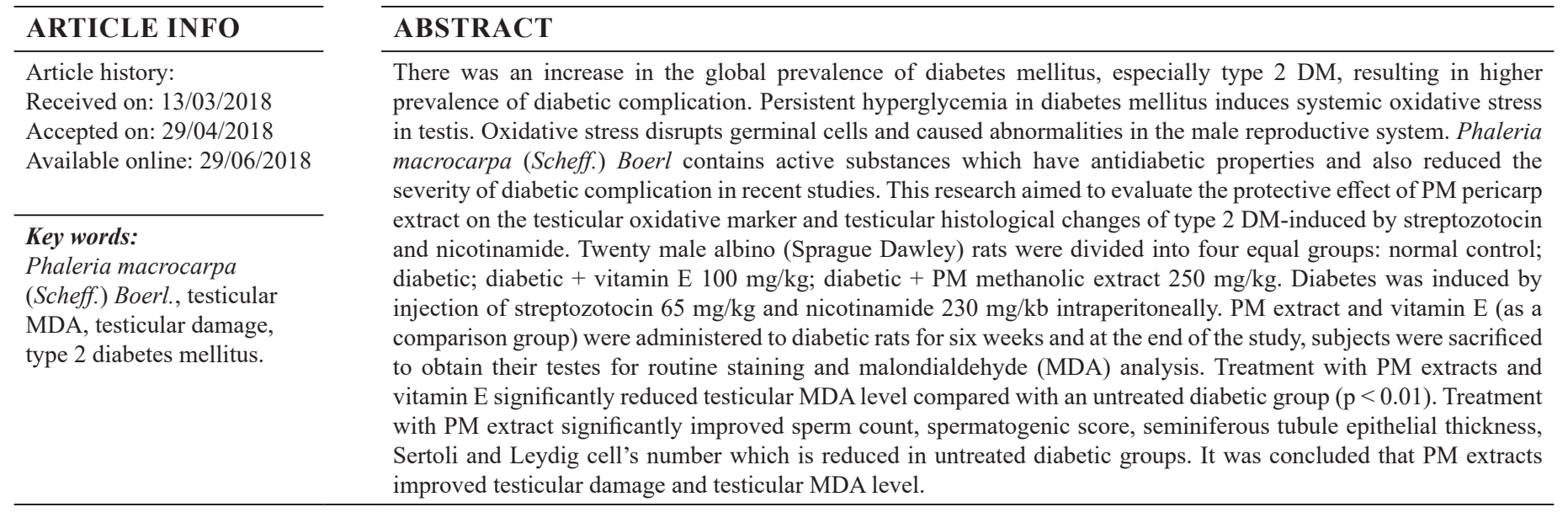

\section{INTRODUCTION}

International Diabetes Foundation estimated that global diabetic prevalence to increase from 366 million in 2011 to 552 million in 2030 (Whiting et al., 2011). Prevalence of diabetes mellitus (DM) among residence above 18 years aged in 2014 had reached $8.5 \%$ of the population. Among four types of diabetes, type 2 diabetes is the most prevalence (World Health

\footnotetext{
${ }^{*}$ Corresponding Author Evy Sulistyoningrum, Histology Department, Faculty of Medicine, Islamic University of Indonesia, Jl. Kaliurang 14,5 Ngemplak, Sleman, Yogyakarta, 55581, Indonesia.E-mail: evysulistyoningrum @ gmail. com; evy.sulistyoningrum@uii.ac.id
}

Organization, 2018). Not only its prevalence continues to rise, but there is a shifting trend to the younger onset of diabetes. This condition happened due to a global increase of population, longer life expectancy, higher prevalence of western lifestyle and obesity (IDF, 2013). The increasing prevalence will be accompanied with complication in multiple organs, one of which is the male reproductive system.

A persistent hyperglycemic condition in diabetes is well known to increase reactive oxygen species (ROS) (Zatalia et al., 2013) which further induce tissue morphological changes involving cellular components of the testis, mostly seminiferous tubules (Alves et al., 2013). Akinola et al. (2015) reported that oxidative stress is one the most agent promoting testicular damage in a diabetic patient, mostly affected lipid membrane of the 
germinal cell and sperm's DNA and further lead to abnormality in sperm structure and function. Male fertility requires the production of large numbers of normal and mature spermatozoa through a complex process which is affected by glucose metabolism (Alves et al., 2013). There is a decline in the number of mature sperms in seminiferous tubule due to diabetes and also in sperm quality due to a lower level of testosterone (Parhizkar et al., 2013). Clinically, infertility occurred in $35 \%$ diabetic patient and this number tends to increase lately (IDF, 2013). Other abnormalities include sexual dysfunction, decreased in sexual libido and impotent. An animal study of diabetes showed changes in sexual behaviors as well as reduced reproductive organs weight and reduced sperm parameter such as sperm count and motility (Alves et al., 2013).

While standard treatment of diabetes only focused on hypoglycemic control, a novel treatment which prevents the complication of diabetes is still needed. Recent studies discover the antidiabetic and protective effect of some natural products, such as Phaleria macrocarpa (Scheff) Boerl (PM). Phaleria macrocarpa is an Indonesian endemic plant, it has been reported to have hypoglycemic activities as an inhibitor of enzyme $\alpha$-glucosidase in diabetic rats (Ali et al., 2012). Previous study suggested that PM had hepatoprotective effect on diabetic rat (Triastuti et al., 2009a) as well as nephroprotective effect on diabetic rats since it was found to reduce renal hypertrophy and blood urea nitrogen level in diabetic rats (Triastuti et al., 2009b) and also reduce expressions of profibrotic factors contributing in diabetic nephropathy (Sulistyoningrum et al., 2013b). In the present study, protection effect of an extract of PM's pericarp on testicular MDA level, sperm count and testicular histological parameters in type 2 diabetes caused by streptozotocin and nicotinamide was examined.

\section{MATERIAL AND METHODS}

\section{Design of the study}

An experimental study (post-test only with control design) was conducted in Integrated Research Laboratory, Islamic University of Indonesia, Yogyakarta, Indonesia from August to December 2016.

\section{Plant material collection}

Merapi Herbal Farma (Yogyakarta, Indonesia) supplied ripe fruits of $P$. macrocarpa. Specimens of the plant was identified by Faculty of Mathematics and Natural Sciences, Islamic University of Indonesia, Yogyakarta, Indonesia. The pericarp of the fruits was sliced, dried in $70^{\circ} \mathrm{C}$ and then grounded into powder. About $1500 \mathrm{~g}$ of the grounded material was added with 6,5 liter methanol for $24 \mathrm{~h}$. The filtrate was collected using Whatman No. 1 filter paper and residu was re-extracted with methanol 6,5 liters for $24 \mathrm{~h}$ and this step was repeated until 2 times. The filtrate from 3 days methanol extraction was collected and evaporated by rotary evaporation. The extracts were kept in the fridge $\left(4^{\circ} \mathrm{C}\right)$ from where aliquots were withdrawn for the test procedures.

\section{Animals and intervention}

In accordance with the Festing formula (Charan \& Khantaria, 2013), a total of 20 healthy male Sprague Dawley rats (Rattus norvegicus) aged 8-12 weeks and weighing $200 \pm$ 25 grams were housed under identical group cages. The cages were occupied in laboratory conditions of $22-30^{\circ} \mathrm{C}$ temperature and $30 \%$ relative humidity and $12 \mathrm{~h}$ light-dark cycle. Animals had free access to a standard pellet diet and mineral water. Prior experiment, rats were adapted for 12 days.

\section{Experimental design}

There were four intervention groups: the normal control group received only distilled water; diabetic control group; diabetic + PM pericarp methanolic extract (PMM), and diabetic + vitamin E. In normal and diabetic control, distilled water was used as a supplement. PM-supplemented groups were given $250 \mathrm{mg} / \mathrm{kg}$, the dose had been administered for renal protective in diabetic rats (Sulistyoningrum et al., 2013). Phaleria macrocarpa extract was weighted using electronic balance (Ohaus PA214, United States of America) and reconstituted in distilled water. Vitamin E (Dexa Medika, Indonesia) and was given in $100 \mathrm{mg} / \mathrm{kg}$ dose (Momeni et al., 2012). All of the working solutions were kept at $4^{\circ} \mathrm{C}$. The working solutions were prepared once a week to prevent any deactivation of the active compound in the extract and to maintain the quality of the working solution. The rats in each group were force-fed with $2 \mathrm{ml}$ working solution according to their treatment groups for six weeks, after which animals were sacrificed under light anesthesia. The epididymal specimen was taken for sperm analysis. Right testis was taken for MDA level analysis and the left testis was taken for routine staining.

\section{Induction of diabetes}

After an overnight fasting, the diabetic condition was induced with a single intraperitoneal injection of Nicotinamide (Sigma Aldrich, United States of America) $230 \mathrm{mg} / \mathrm{kg}$ and 65 $\mathrm{mg} / \mathrm{kg}$ streptozotocin (Nacalai Tesque, Japan) dissolved in citrate buffer 4,5 pH with 15 minutes interval. After $72 \mathrm{~h}$ of induction, hyperglycemia was confirmed by measuring fasting blood glucose level taken from tail capillary with a glucometer (GlucoDr AGM 2100 , Korea). Rats with a fasting blood glucose level above 130 $\mathrm{mg} / \mathrm{dl}$ were considered diabetic and employed for further studies (Sedigheh et al., 2011).

\section{Testicular malondealdehide analysis}

Testicular MDA levels were determined using the procedure of Ohkawa (Akondi et al., 2011). After thawing the tissues, each sample was weighed and homogenized in $0,15 \mathrm{M}$ potassium chloride solution; about $0,4 \mathrm{~mL}$ of homogenate was mixed with $1.5 \mathrm{~mL}$ thiobarbituric acid, $1.5 \mathrm{~mL}$ acetic acid $(\mathrm{pH} 3.5)$, and $0.2 \mathrm{~mL}$ sodium dodecyl sulfate. A set of MDA standard was freshly prepared. After mixing, all samples and standards were heated at $95^{\circ} \mathrm{C}$ for 1 hour and cooled under tap water. The absorbance was recorded at $532 \mathrm{~nm}$ and compared with those obtained from MDA standards. The results were expressed as $\mathrm{nmol} / \mathrm{mg}$ tissue.

\section{Histological analysis}

Left testis from each animal was removed and placed in $10 \%$ buffer formalin, cast in paraffin. Isolated organs were stained with Hematoxylin-Eosin and then examined for the morphology. Quantitative analysis of histological reproductive parameters was carried out by determination of the spermatogenesis score, a number of spermatogonia cells, Sertoli cells, Leydig cells and seminiferous tubules epithelial thickness were measured with Olympus CX22 and Optilab Viewer (Miconos, Yogyakarta, 
Indonesia). Regarding spermatogenesis score, spermatogenesis in seminiferous epithelia were scored semiquantitatively into ten scales according to Johnsen score on spermatogenesis (1, no cells were found in the seminiferous epithelia; 2 , only Sertoli cell were found in the epithelia; 3 : only spermatogonia in the epithelia; 4: spermatocytes less than 5, no spermatid and spermatozoa; 5: many spermatocytes, no spermatid and spermatozoa; 6: spermatid less than 10, no spermatozoa; 7: many spermatids, no spermatozoa; 8: spermatozoa less than 10; 9: many spermatozoa, unorganized spermatogenesis, sloughing seminiferous epithelia, closed lumen; 10: complete and well-organized spermatogenesis, open lumen (Iftikhar et al., 2014). About 25 seminiferous tubules were analyzed in the testicular sections of each rat.

\section{Sperm analysis}

Sperm count analysis was performed according to Parhizkar et al. (2013) with slight modification using the hemocytometer. A drop with $10 \mu$ of caudal epididymal sperm solution was loaded under the coverslip on the hemocytometer and then examined in 400x magnification under Olympus CX 22 light microscope. Counting was only performed for sperm heads that were found within $4 \times 4$ squares (horizontally or vertically) and calculated using the formula below:

Sperm count $=($ total number of sperm in 5 squares $) \times$ $($ solution $) \times 0,05 \times 100^{6}($ cells $/ \mathrm{ml})$

\section{Statistical analysis}

Normally distributed data were expressed as mean \pm SD and analyzed using one way ANOVA and Tukey HSD post hoc test for multiple comparisons. Skewed distributed data were analyzed using Kruskal Wallis and were further subjected to Mann-Whitney post hoc. All analyses were performed with IBM SPSS 15.00 version 21 and differences between means were accepted significant at $\mathrm{p}<0.05$.

\section{Ethical clearance}

Ethical approval for this study was obtained from Research Ethics Committee, Faculty of Medicine, Islamic University of Indonesia (Registration number 21/Ka.Kom.Et/70.KE.VI/2015).

\section{RESULT AND DISCUSSION}

Research for investigating the effect of Phaleria macrocarpa extract on the testicular complication of type 2 diabetic rats was conducted for 6 weeks. Induction of type 2 DM with an injection of STZ and NAD significantly elevated fasting glucose level (Table 1). During interventions, animal were in proper condition. There was no report of abnormality in appetite, the volume of feces and urine, except in untreated diabetic group, animals had a slower weight gain and an increase of urine volume which need cage cleaning more frequent.

Table 1: Characteristic of subjects

\begin{tabular}{ccccc}
\hline Group & n & Weight prior treatment (gram) & Weight after treatment (gram) & Fasting glucose level prior treatment (mg/dl) \\
\hline I & 5 & $220,76 \pm 16,90$ & $244,98 \pm 12,90$ & $88,20 \pm 14,28$ \\
II & 5 & $214,74 \pm 15,81$ & $208,98 \pm 11,41$ & $152,20 \pm 14,02^{*}$ \\
III & 5 & $213,70 \pm 11,79$ & $227,18 \pm 13,62$ & $163,40 \pm 12,69^{*}$ \\
IV & 5 & $210,50 \pm 15,01$ & $213,94 \pm 13,35$ & $154,20 \pm 24,68^{*}$ \\
\hline
\end{tabular}

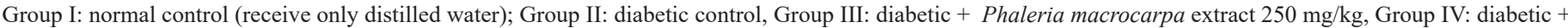
vitamin E $100 \mathrm{mg} / \mathrm{kg}$, *p < 0,05 compared with Group I (ANNOVA followed by post hoc LSD).

Testicular MDA level of untreated diabetic rats was significantly higher than other groups (Figure 1), treatment with vitamin $\mathrm{E}$ and $\mathrm{PM}$ extract significantly reduced testicular MDA level ( $p<0,05$ compared with untreated diabetic groups). Group treated with vitamin $\mathrm{E}$ had no significant difference in testicular MDA level compared with normal group, while the group with PM extract still gave a higher MDA level compared with normal group $(\mathrm{p}<0,05)$. Diabetic rats also showed a significant reduction in sperm count of epididymal suspension (Figure 2). The diabetic group received treatment with PM extracts and vitamin $\mathrm{E}$ had higher sperm count ( $p<0,05$ compared with the diabetic group, Figure 2), but still lower than normal group $(\mathrm{p}<0,05)$.

Majority of seminiferous tubule in Group I were intact, prominent and had an optimal epithelial thickness (Figure 3a) and a small amount of interstitial component. In higher magnification, seminiferous epithelium showed complete spermatogenesis, consist of many spermatogenic cells ranging from immature (spermatogonia) to mature stadia (spermatozoa) (Figure 4a) and Sertoli cells characterized by triangular shape, located in the basal compartment of seminiferous tubule and prominent nuclei.

In an untreated diabetic group, the majority of seminiferous tubule had a low epithelial thickness (Figure 3b).
There was also abnormal changes in interstitial compartment, that showed a loose connection, and sparse distribution of seminiferous tubule. In higher magnification, there was a depletion in the epithelial spermatogenic cells and heterogeneity of spermatogenesis. The diabetic group received Phaleria macrocarpa extract showed many tubuli with variability in sizes and epithelial thickness, some sparse elements in the interstitial compartment (3c). The diabetic group received vitamin $\mathrm{E}$ showed many tubuli with variability in sizes and optimal epithelial thickness In higher magnification, both in vitamin E and PMM extract groups, all stages of spermatogenic cells were observed in the epithelium but not as optimum as normal control.

Diabetes group had lowest spermatogenesis score, also other histological parameters in seminiferous tubule, including epithelial thickness, Sertoli cell's number (Table 2). The diabetic group received Phaleria macrocarpa extract and vitamin E showed improvement in spermatogenesis score, seminiferous tubules' epithelial thickness, and Sertoli cell number. The diabetic group received PMM extract and vitamin E showed an improvement in histological parameter indicated by improved epithelial thickness and spermatogenesis score compared with an untreated diabetic group ( $p<0,05$, Table 2 ). Improvement also 
can be reported on Sertoli cell's number, which was responsible for structural support of spermatogenic cell, also in nourishment, the secretory cell produces androgen binding protein and inhibin. In Figure 4, Sertoli cells were characterized by triangular nuclei, located at the basal compartment of seminiferous tubule and apical segment elongated at luminal compartment (arrow). The diabetic group treated with vitamin E showed better improvement on spermatogenesis score and epithelial thickness than PM and the result is not significantly different with the normal group. On the contrary, there were no significant differences on spermatogonia cell count among 4 groups ( $\mathrm{p}>0,05$, Table 2).

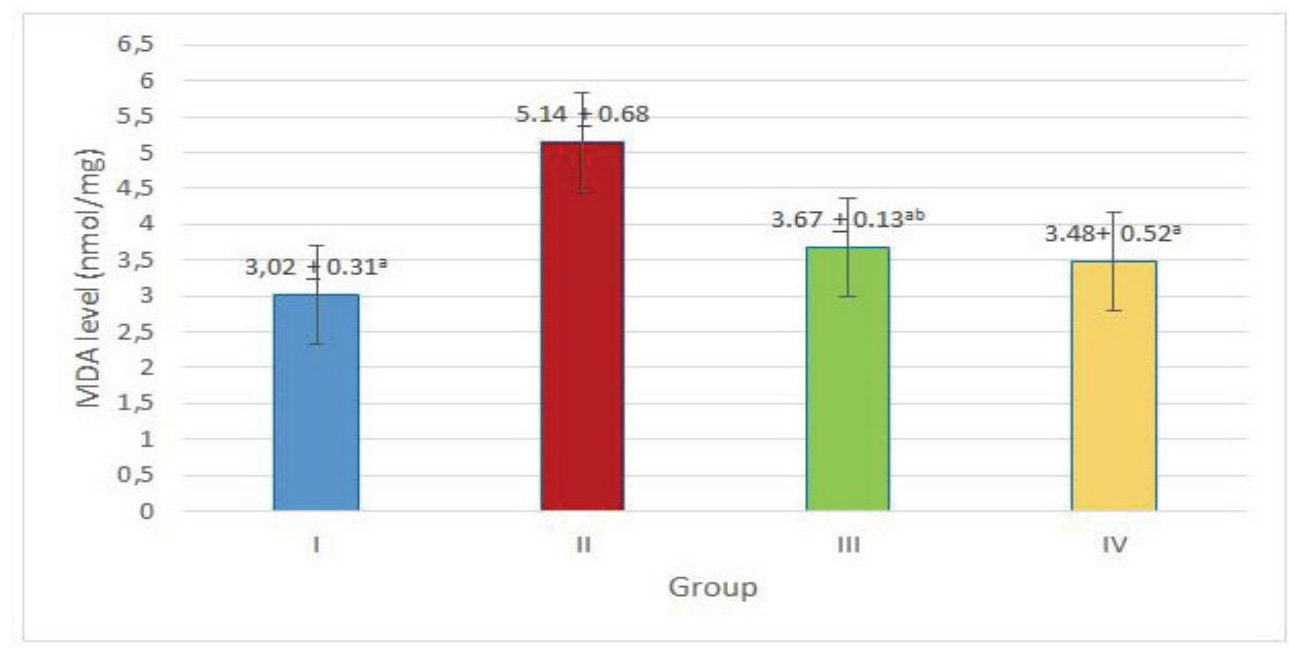

Fig. 1: Testicular MDA level. Group I: normal control (receive only distilled water); Group II: diabetic control: Group III: diabetic + Phaleria Macrocarpa extract $250 \mathrm{mg} / \mathrm{g}$, Group IV: diabetic + vitamin E $100 \mathrm{mg} / \mathrm{kg}$ : ${ }^{\mathrm{a}} \mathrm{p}<0,05$ compared with Group II, ${ }^{b} \mathrm{p}<0,05$ compared with Group I (ANNOVA followed by post hoc LSD).

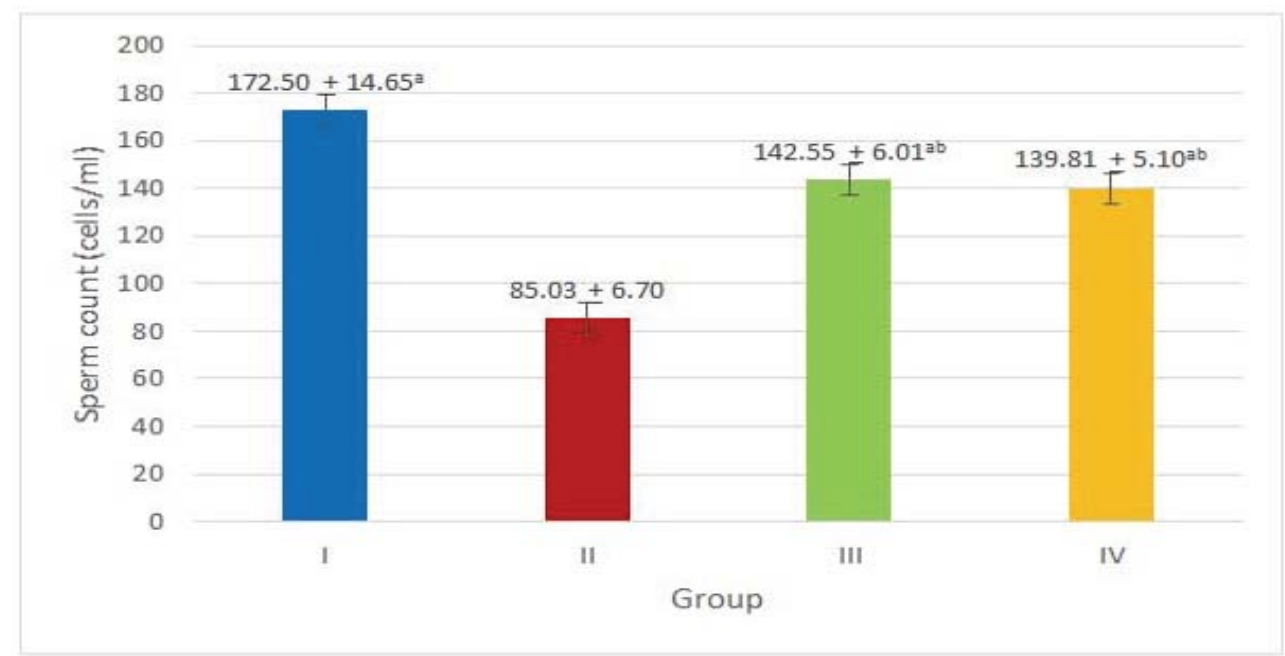

Fig. 2: Epididymal sperm count. Group I: normal control (receive only distilled water); Group II: diabetic control, Group III: diabetic + Phalerfa Macrocarpa extract $250 \mathrm{mg} / \mathrm{kg}$, Group IV: diabetic + vitamin E $100 \mathrm{mg} / \mathrm{kg},{ }^{a} \mathrm{p}<0,05$ compared with Group II. ${ }^{b} \mathrm{p}<0,05$ compared with Group I (ANNOVA followed by post hoc LSD).

On interstitial compartment, the diabetic group had an accumulation of loose connective tissue in interstitial (Figure $3 b$ ) and reduced number of Leydig cells (Table 2). This cell is responsible for testosterone secretion and it is characterized by prominent nuclei, acidophilic cytoplasm and variable lipid droplet in the cytoplasm (Figure 5, arrow). The normal group had the most Leydig cell's number, followed by vitamin E group, PMM extract group, and the untreated diabetic group had the less. Treatment with vitamin E and PMM extract improved Leydig cell's number ( $\mathrm{p}<0,05$, Table 2), but vitamin E showed better improvement in Leydig cell number and had no different with the normal group.
Induction of streptozotocin $65 \mathrm{mg} / \mathrm{kg}$ and nicotinamide $230 \mathrm{mg} / \mathrm{kg}$ intraperitoneally can increase blood glucose level above the normal level. Streptozotocin (STZ) is a selective toxic substance for pancreatic beta cells, which enter the cells via glucosa-2 transporter (GLUT-2) (Eleazu et al., 2013). Streptozotocin inhibits insulin secretion via ATP reduction and NAD depletion in cells' DNA. Combined with nicotinamide $230 \mathrm{mg} / \mathrm{kg}$, STZ will induce more stable and irreversible diabetic condition (Khaneshi et al., 2013). This combination also induces a clinical condition of diabetes without plasma insulin reduction (Alkhamees, 2013) and also induced diabetes complications (Ghasemi et al., 2014). 

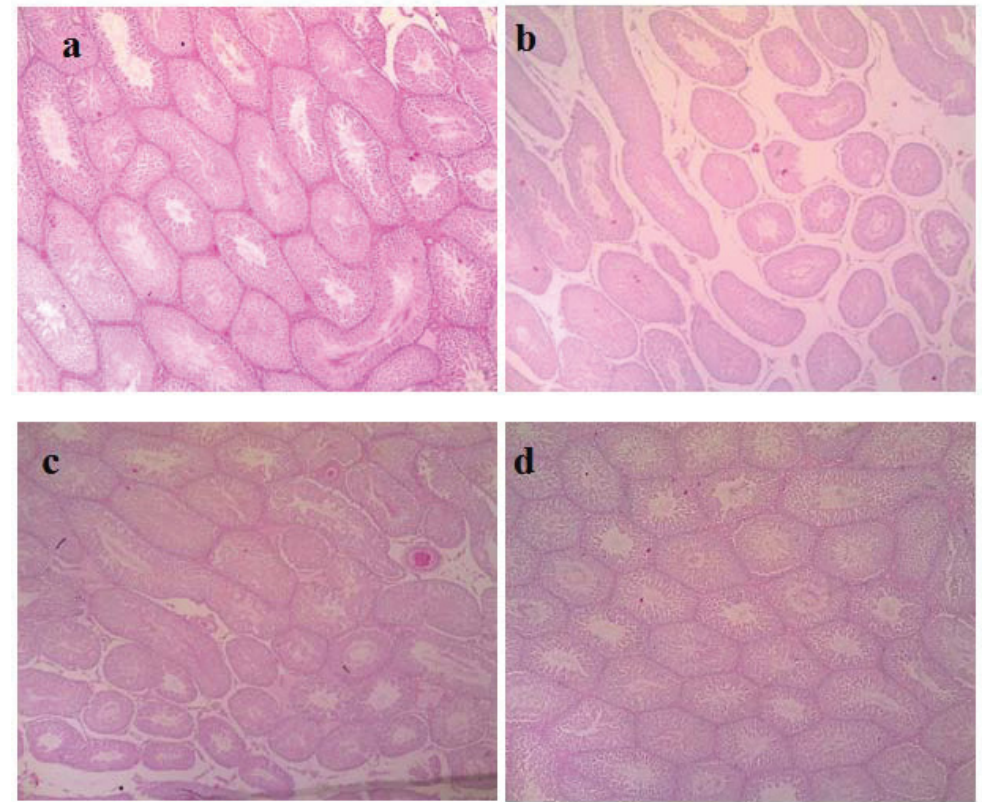

Fig. 3: Lower magnification of testicular tissue among groups. 100x magnification, Routine staining. Normal seminiferous tubule and lesser interstitial compartment in Group I (a). In Group II: seminiferous tubule were smaller and had plenty of interstitial component (b), Group III showed many tubuli with variability in size and epithelial thickness while in Group IV showed many tubules with intact epihelium similar to Group I. Group I: normal control (receive only distilled water); Group II: diabetic control, Group III: diabetic + Phaleria macrocarpa extract $250 \mathrm{mg} / \mathrm{kg}$, Group IV: diabetic + vitamin E $100 \mathrm{mg} / \mathrm{kg}$.
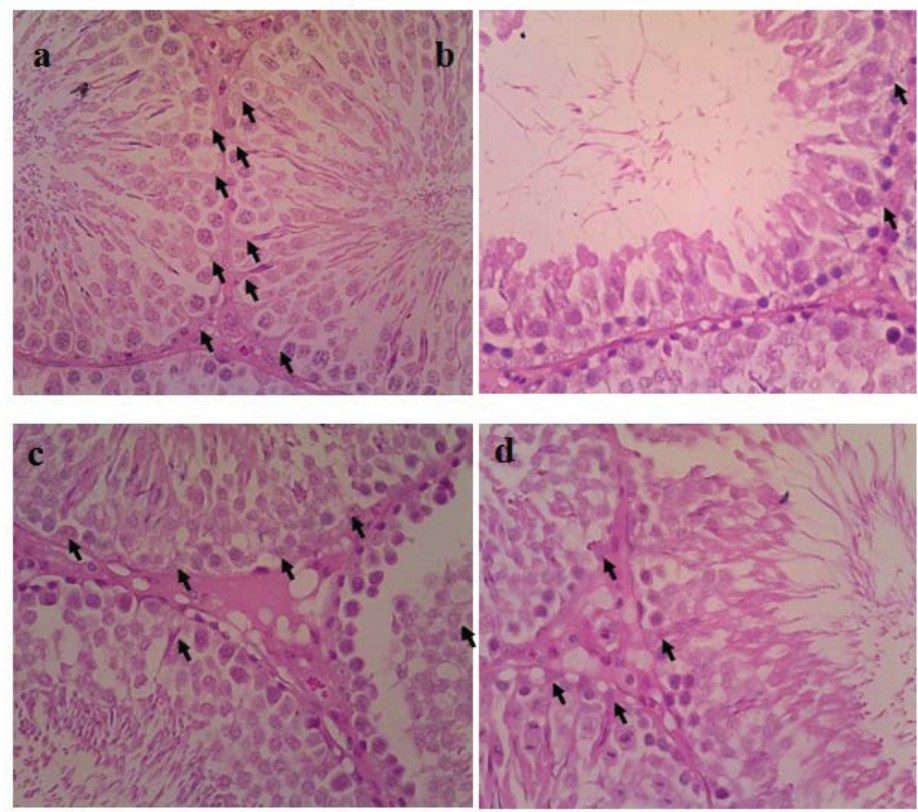

Fig. 4: Higher magnification of seminiferous tubules among groups. 400x magnification, Routine staining. Group I (a) had thick epithelial layer and optimal spermatogenesis (score 10) and man Sertolli cells (arrow). Group II (b) showed epithelial depletion and less spemiatogenic cells observed, less mature stage of spennatogenic cells, Groups III and IV (c and d) showed thick epithelial layer and complete stages of spennatogenic cells but not yet as optimum as Group I. Group I: normal control (receive only distilled water); Group II: diabetic control; Group III: diabetic + Phleria macrocarpa extract $250 \mathrm{mg} / \mathrm{kg}$, Group IV: diabetic + vitamin E $100 \mathrm{mg} / \mathrm{kg}$.

The untreated diabetic rat had high testicular MDA level indicating oxidative stress in testicular tissue followed by reducing sperm count. Testicular MDA level is an indicator for lipid peroxidation in spermatogenic cell's membrane. This substance had a toxic effect on to the spermatozoa, an eventually will reduce spermatozoa's cell membrane integrity and lead to lower quality of the sperm. Streptozotocin and diabetes condition caused marked increased of MDA level (Ramzy et al., 2014).

Diabetic group had the lowest seminiferous tubule epithelial thickness and spermatogenesis score. Consistent with this research, Ozdemir et al. (2009) reported that diabetic rats had low seminiferous tubule epithelial thickness due to 
decreased spermatogenesis and spermatogenic cells' apoptosis in seminiferous epithelial. ROS-induced apoptosis also occurred in interstitial compartment, affected Leydig cell so the number of Leydig cells decreased and there was an accumulation in loose connective tissue in the interstitium. STZ-induced diabetic rats also had atrophy in reproductive organs and decrease sperm parameters (Navarro-Casado et al., 2010).

Table 2: Mean of histological parameters.

\begin{tabular}{ccccccc}
\hline Group & $\mathbf{n}$ & Spermatogenesis score & Epithelial thickness $(\boldsymbol{\mu m})$ & Spermatogonia cell number & Sertoli cell number & Leydig cell number \\
\hline I & 5 & $8,56+0,41^{\mathrm{a}}$ & $100,46 \pm 2,13^{\mathrm{a}}$ & $616,2 \pm 77,95$ & $89,40 \pm 4,27^{\mathrm{a}}$ & $17,42+0,52^{\mathrm{a}}$ \\
II & 5 & $5,88+0,26$ & $81,43 \pm 5,99$ & $469,8 \pm 105,23$ & $61,80 \pm 6,44$ & $8,34+0,59$ \\
III & 5 & $8,06+0,33^{\mathrm{ab}}$ & $89,66 \pm 1,10^{\mathrm{ab}}$ & $502,4 \pm 97,36$ & $87,80 \pm 4,48^{\mathrm{a}}$ & $13,41+0,44^{\mathrm{ab}}$ \\
IV & 5 & $8,32+0,19^{\mathrm{a}}$ & $94,73 \pm 1,95^{\mathrm{a}}$ & $531,2 \pm 118,83$ & $88,00 \pm 5,58^{\mathrm{a}}$ & $17,44+0,39^{\mathrm{a}}$ \\
\hline
\end{tabular}

Group I: normal control (receive only distilled water); Group II: diabetic control, Group III: diabetic + Phaleria macrocarpa extract $250 \mathrm{mg} / \mathrm{kg}$, Group IV: diabetic + vitamin E $100 \mathrm{mg} / \mathrm{kg},{ }^{a} \mathrm{p}<0,05$ compared with Group II, ${ }^{\mathrm{b}} \mathrm{p}<0,05$ compared with Group I (ANNOVA followed by post hoc LSD).

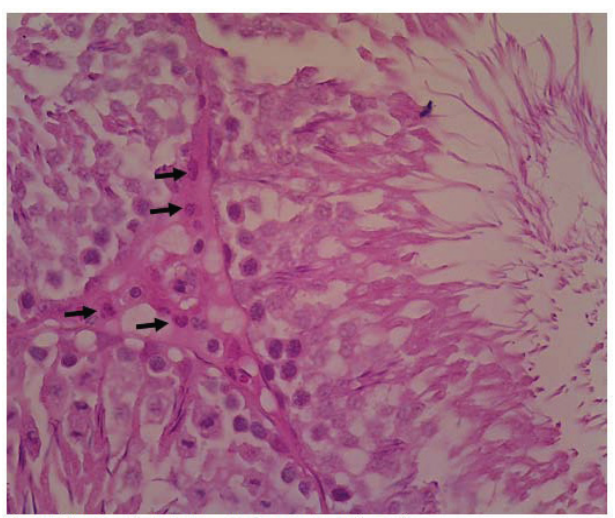

Fig. 5: Leydig cells in the interstitial compartment (arrows).

Treatment with Phaleria macrocarpa extract and vitamin E improved testicular MDA level, indicated that both Phaleria macrocarpa and vitamin E can decrease oxidative stress parameter in the testes tissue. Vitamin $\mathrm{E}$ is a potent non-enzymatic antioxidant which naturally presents in cellular membrane (Agarwal et al., 2014). Vitamin E can reduce cytotoxicity, minimalize oxidation effect of lipoprotein, suppressed vascular smooth muscle proliferation, reduce adhesion and proliferation of platelets and increase endothelial function (Jameson et al., 2015). Consistent with this study, Zatalia et al. (2013) reported that treatment with vitamin E in STZ-NAD-induced diabetic rats showed reduced lipid peroxidation activity, glutathione peroxidase (GSH-Px), and glutathione transferase (GSH). Han et al. (2010) reported that vitamin $\mathrm{E}$ also had a protective effect on oxidative stress and prevent cellular damage caused by excessive production of ROS in unilateral orchidectomy rat model. Consistent with this result, Fahim et al. (2012) also reported that vitamin E can prevent decreased sperm count on lead-induced testicular oxidative stress model, reduced ultrastructural damage on spermatid cell, epididymal epithelial and Leydig cell. Vitamin E also protects testis from aging characterized by reduce in testicular MDA level and histological parameters (Aybek et al., 2008) and STZ-induced diabetes (Kaplanoglu et al., 2013).

Treatment with Phaleria macrocarpa's extract showed a protective effect on testicular damage indicated by improved histological parameter compared with an untreated diabetic rat. Phaleria macrocarpa contains many active substances which had antioxidant properties such as saponin, phalerin dan flavonoid
(Ali et al., 2012), and also triterpenoids (Lay et al., 2014). Supplementation of antioxidants had no effect on plasma glucose nor insulin level but antioxidant significantly reduced $\mathrm{HbAlc}$ and prevent the complication of diabetes. Flavonoids of Phaleria macrocarpa can act as a free radical scavenger, reduce peroxidase lipid and increase hepatic glutathione activity (Zatalia et al., 2013). Flavonoids of Phaleria macrocarpa are kaempferol, myricetin, naringin, rutin and quercetin, which act as an antioxidant by inhibiting oxidation reaction and reduction of hydroxyl radical (Hendra et al., 2011). Flavonoid and saponin inhibit apoptosis of testicular germinal cell in diabetic rats (Mallick et al., 2010) and also had a cytoprotective effect on a testicular cell (Shalaby, 2010). Flavonoid also can improve spermatogenesis on diabetic rats. Parhizkar et al. (2013) reported that Phaleria macrocarpa had a positive effect on testicular histology and sperm parameter of normal rats. Saponin of Phaleria macrocarpa stimulates testosterone production and further will increase spermatogenesis activity.

Recently, many studies reported the benefits of PM extract treatment in diabetes condition and also a diabetic complication. Phaleria macrocarpa has been reported to have hypoglycemic activities detected in random blood glucose level as well as fasting blood glucose level and also improve intraperitoneal glucose tolerance (Gopalan et al., 2016). A previous study suggested that PM had regenerative/recovery effect on pancreatic $\beta$ cells (Salih et al., 2015). Regarding diabetic complication, PM treatment also reduce renal hypertrophy and blood urea nitrogen level in diabetic rats (Triastuti et al., 2009b), improve histological findings of renal glomeruli (Sulistyoningrum et al., 2013a) and also reduce expressions of profibrotic factors contributing in diabetic nephropathy (Sulistyoningrum et al., 2013b).

Although many positive results of Phaleria macrocarpa in improving testicular damage, this research found no difference on spermatogonia cell number among four groups. This research limited only count for dark spermatogonia cell while pale spermatogonia contributed as spermatogenic cells were difficult to identify in routine staining. Dark spermatogonia cell acts as inactive reserve cell in the seminiferous cell epithelial. This result was not consistent with Kianifard et al. (2012) that reported that in diabetic rats, the number of active spermatogonia was decreased, while the number of inactive spermatogonia was increased. Routine staining is unable to detect proliferation activity of spermatogonia. A specific method for cell proliferation such as a proliferative cell 
nuclear antigen (PCNA) and KI67 immunostaining will give a specific and representative result on proliferating spermatogonia. Further investigation in safety of Phaleria macrocarpa is needed before implementing this research to the clinical setting.

In this research, degree of improvements on sperm count, spermatogenesis score, seminiferous tubule epithelial thickness, Sertoli and Leydig cell's number of PM treated group seems not as good as or similar to Vitamin E. However, PM treatment can still be considered as alternative drug since it has benefit on testicular tissue as well as other properties of diabetic condition such as antihyperglycemic, antioxidant and renal protective due to diabetic-related complication. Given orally, treatment of PM extract can be used as a better comprehensive treatment of diabetes and its complication compared with vitamin $\mathrm{E}$ alone.

\section{CONCLUSION}

In brief, it can be concluded that Phaleria macrocarpa extract improved testicular oxidative stress parameter, sperm count and histological changes of the testis, which characterized by spermatogenesis score and histological morphometric parameters. In type 2 diabetes mellitus induced by streptozotocin and nicotinamide, there was an increase of testicular MDA level and a decrease of a histological parameter of spermatogenesis. However, improvement of Phaleria macrocarpa extracts not yet give the equal result as vitamin $E$ treated group nor normal control. One of possible future implementation of this research is the use of PM extract as a complementary treatment for a testicular complication of type 2 diabetes mellitus.

\section{ACKNOWLEDGMENTS}

This research study was funded by a research grant from the Faculty of Medicine, Islamic University of Indonesia. We express our gratitude to Mrs. Ernadita Budiasri for giving us support for this research.

\section{CONFLICT OF INTERESTS}

There are no conflict of interests.

\section{REFERENCES}

Agarwal A, Virk G, Ong C, Plessis SSD. Effect of Oxidative Stress on Male Reproduction. World J Mens Health, 2014; 32(1):1-17.

Akinola OB, Dosumu OO, Sanusi SA, Ajayi TF, Olajide TH. PPAR-c agonist pioglitazone improves semen quality and testicular histomorphometrics with partial reversal of hyperglycaemia in alloxan-induced diabetic rats. Middle East Fertility Society Journal, 2015; 20(4):271-279.

Akondi BR, Challa SR, Akula A. Protective Effects of Rutin and Naringin in Testicular Ischemia-Reperfusion Induced Oxidative Stress in Rats. J Reprod Infertil, 2011; 12(3):209-214.

Ali R, Atangwho I, Kaur N, Abraika O, Ahmad M, Mahmud R, et al. Bioassay-Guided Antidiabetic Study of Phaleria macrocarpa Fruit Extract. Molecules Journal, 2012; 17:4986-5002.

Alkhamees OA. Quercetin Attenuates Testicular Damage and Oxidative Stress in Streptozotocin-induced Diabetic Rats. British Journal of Pharmacology and Toxicology, 2013; 5(2):88-97.

Alves M, Martins A, Rato L, Moreira P, Socorro S, Oliveira P. Molecular mechanisms beyond glucose transport in diabetes-related male infertility. Biochemica et Biophysica Acta, 2013; 1832:626-635.

Arikawe A. Comparison if Streptozotocin-induced Diabetic and Insulin Resistant Effects on Spermatogenesis with Proliferating Cell Nuclear Antigen (PCNA) Immunostaining of Adult Rat Testis. Journal of Experimental and Clinical Medicine, 2012; 29:209-14.
Aybek, H, Aybek Z, Rota S, Sen N, Akbulut M. The effects of diabetes mellitus, age and vitamin $\mathrm{E}$ on testicular oxidative stress. Fertility and Sterility, 2008; 90:755-760.

Charan J, Kantharia ND. How to calculate sample size in animal studies? Journal of Pharmacology \& Pharmacotherapeutics, 2013; 4(4):303-06.

Eleazu CO, Eleazu KC, Chukwuma S, Essien UN. Review of the mechanism of cell death resulting from streptozotocin challenge in experimental animals, its practical use and potential risk to humans. Journal of Diabetes \& Metabolic Disorders, 2013; 12:60.

Fahim MA, Tariq S, Adeghate E. Vitamin E modifies the ultrastructure of testis and epididymis in mice exposed to lead intoxication. Annals of Anatomy, 2012; 195:272-277.

Ghasemi A, Khalifi S, Jedi S. Streptozotocin-nicotinamideinduced Rat Model of Type 2 Diabetes (Review). Acta Physiologica Hungarica, 2014; 101(4):408-20.

Gopalan HK, Azmi N, Roslan FH, Salih ND. The AntiHyperglycemic Effects of Phaleria macrocarpa Leaves Extract on Streptozotocin-Induced Diabetic Rats. International Journal of Advances in Science Engineering and Technology, Suppl, 2016(2):180-183. Available from: https://www.researchgate.net/publication/297737741_The AntiHyperglycemic_Effects_of_Phaleria_macrocarpa_Leaves_Extract_On_ Streptozotocin-Induced_Diabetic_Rats [accessed Apr 28 2018].

Han WK, Jin MH, Han SW. Effect of vitamin E on oxidative stress in the contralateral testis of neonatal and pubertal hemicastrated rats. Journal of Pediatric Urology, 2010; 8:67-71.

Hendra R, Ahmad S, Oskoueian E, Sukari A, Shukor Y. Antioxidant, anti-inflammatory and cytotoxicity of Phaleria macrocarpa (Boerl.) scheff fruit. BMC Complementary and Alternative Medicine, 2011; 11:110.

Iftikhar S, Ahmad M, Aslam HM, Saeed T, Arfat Y, Nazish GE, Evaluation of spermatogenesis in prepubertal albino rats with date palm pollen supplement. African Journal of Pharmacy and Pharmacology, 2014; $8(2): 59-65$.

International Diabetes Federation. 2013. IDF Diabetes Atlas Sixth Edition. Nolan, USA.

Jameson VJA, Cocheme HM, Logan A, Hanton LR, Smith RAJ, Murphy MP. Synthesis of triphenylphosphonium vitamin E derivatives as mitochondria-targeted antioxidants. Tetrahedron, 2015; 71:8444-8453.

Kaplanoglu GT, Bahcelioglu M, Gozil R, Helvacioglu F, Buru E, Tekindal ME, Erdogan D, Calguner E. Effects of green tea and vitamin E in the testicular tissue of streptozotocin-induced diabetic rats. Saudi Medical Jornal, 2013; 34(7):734-743.

Khaneshi F, Nasrolahi O, Azizi S, Nejati V. Sesame effects on testicular damage in streptozotocin-induced diabetes rats. Avicenna Journal of Phytomedicine, 2013: 3(4):347-355.

Kianifard D, Sadrkhanlou RA, Hasanzadeh S. The Ultrastructural Changes of The Sertoli and Leydig Cells Following Streptozotocin Induced Diabetes. Iranian Journal of Basic Medical Sciences, 2012; 15(1):623-35.

La Vignera S, Condorelli R, Vicari E, D'Agata R, Calogero AE. Diabetes mellitus and sperm parameters. Journal of Andrology, 2012; 33(2):145-53.

Lay MM, Karsani SA, Banisalam B, Mohajer S, Malek SNA. Antioxidants, Phytochemicals, and Cytotoxicity Studies on Phaleria macrocarpa (Scheff.) Boerl Seeds, BioMed Research International, 2014: 1-13.

Mallick C, Bera TK, Ali KM, Chatterjee K, Ghosh D. Diabetes induced testicular disorders vis-a-vis germ cell apoptosis in albino rat: Remedial effect of hexane fraction of root of Musa paradisiaca and leaf of Coccinia indica. J Health Sci, 2010; 56:641-654.

Momeni HR, Eskandari N. Effect of vitamin E on sperm parameters and DNA integrity in sodium arsenite-treated rats. Iran Journal Reproductive Medicine, 2012; 10(3):249-256.

Navarro-Casado, L, Juncos-Tobarra MA, Chafer-Rudilla M, de Onzono LI, Blazquez-Cabrera JA, Miralles-Garcia JM. Effect of experimental diabetes and STZ on male fertility capacity. Study in rats. Journal of Andrology, 2010; 31:584-592. 
Ozdemir O, Akalin PP, Baspinar N, Hatipoglu F, Pathological Changes In The Acute Phase Of Streptozotocin-Induced Diabetic Rats, Bull Vet Inst Pulawy, 2009; 53:783-790.

Parhizkar S, Yusoff MJ, Dollah MA. Effect of Phaleria macrocarpa on Sperm Characteristics in Adult Rats. Advanced Pharmaceutical Bulletin, 2013; 3(2):345-352.

Ramzy MM, El-Sheikh AAK, Kamel MY, Abdelwahab SA, Morsy MA. Mechanism of Testicular Protection of Carvedilol in Streptozotocin-Induced Diabetic Rats, Indian J. Pharmacol, 2014; 46(2):161-165.

Salih ND, Azmi N, Gopalan HK. The Protective Effects of Phaleria macrocarpa Leaves Methanol Extract on Pancreatic Islets Histology in Streptozotocin-Induced Diabetic Rats. Science International (Lahore), 2015; 27(5):4219-224. Available from: https://www.researchgate. net/publication/284624147_The_Protective_Effects_of_Phaleria_ macrocarpa_Leaves_Methanol_Extract_on_Pancreatic_Islets_Histology_ in_Streptozotocin-Induced_Diabetic_Rats [accessed Apr 28 2018].

Shalaby MA, Mouneir SM. Effect of Zingiber officinale Roots and Cinnamon zeylanicum Bark on Fertility of Male Diabetic Rats, Global Veterinaria, 2010; 5 (6):341-347.

Sedigheh A, Jamal MS, Mahbubeh S, Somayeh K, Mahmoud RK, Azadeh A, et al. Hypoglycaemic and hypolipidemic effects of pumpkin (Cucurbita pepo L.) on alloxan-induced diabetic rats, African Journal of Pharmacy and Pharmacology, 2011; 5(23):2620-2626.

Sulistyoningrum E, Setiawati,Ismaulidhya FR. Phaleria macrocarpa (Scheff) Boerl improved renal histological change in alloxan induced diabetic rats. International journal of medicinal plant and alternative medicine, 2013a; 1(5):87-92.

Sulistyoningrum E, Setiawati. Phaleria macrocarpa reduces glomerular growth factor expression in alloxan-induced diabetic rats Universa Medicina, 2013b; 32(2):71-79.

Triastuti A, Hee-JP, Jong WC. Phaleria macrocarpa Suppresses Oxidative Stress in Alloxan-Induced Diabetic Rats by Enhancing Hepatic Antioxidant Enzyme Activity. Natural Product Sciences, 2009a; 15(1):37-43.

Triastuti A, Park HJ, Choi JW. Phaleria Macrocarpa Supress Nephropathy by Increasing Renal Antioxidant Enzyme Activity in Alloxan Induced Diabetes Rats. Natural Product Sciences, 2009b; 15(3):167-172.

Whiting DR, Guariguata DR, Weil C, Shaw J. IDF Diabetes Atlas: Global Estimates of The Prevalence of Diabetes for 2011 and 2030. Diabetes Research and Clinical Practice, 2011; 94:311-21.

WHO. Diabetes. Available at http://www.who.int/mediacentre/ factsheets/fs312/en/ (updated November 2017, accessed 12 February 2018).

Zatalia SR, Sanusi H. The Role of Antioxidants in the Pathophysiology, Complications, and Management of Diabetes Mellitus. Acta Medica Indonesiana, 2013; 45(2):141-7.

How to cite this article:

Sulistyoningrum E, Pradipta DM, Fanana S, Haikhah JA, Putro MDH. Protective effect of Phaleria macrocarpa (Scheff.) Boerl extract on the testicular damage of streptozotocin and nicotinamide-induced type 2 diabetic rats. J App Pharm Sci, 2018; 8(06): 139-146. 